\title{
BOUNDARIES IN THE REAL ESTATE CADASTRE - ESTABLISHMENT OF BOUNDARIES IN THE LAND AND BUILDING RECORDS
}

\author{
Szczepan Budkowski, Jacek Gniadek
}

\section{Summary}

In Poland, the land and building records serve as the real estate cadastre and are subject to periodic and ongoing updating in accordance with applicable regulations. The district governor (starosta) is obliged to keep records of land and buildings. Descriptive data is kept by land and mortgage courts. The correct plot designation in the register defines the property as a subject of legal circulation. The purpose of the present publication is to clarify the problems associated with establishing the boundaries of registration plots in the context of the possibility of using a multidimensional cadastre. The publication also contains an assessment of selected technical and legal aspects related to the above-mentioned tasks.

\section{Keywords}

land and building records $\bullet$ multidimensional cadaster $\bullet$ legal boundary

\section{Introduction}

The land and building records, as the basic information system on the area, provide data for the needs of spatial planning, real estate management, tax and benefits assessment, farm records, as well as the marking of real estate in land and mortgage registers. According to the law defined in this respect by the Act on Geodetic and Cartographic Law [Prawo geodezyjne i kartograficzne i.e. PGIK], land and building records constitute an information system designed to provide current data on:

- land, their location, borders, types of land use, land and mortgage registers designation,

- buildings, location, purpose, as well as utility function and technical data,

- (usable) premises - their location as well as their function and usable area.

In addition to the material scope, the land and building records also apply to information on the following entities:

- the owners, that may be local government units, the State Treasury, natural or legal persons, 
- property holders who do not own the property rights but actually dispose of the property.

From a formal point of view, keeping records of land and buildings is the responsibility of the starosta (district governor) [EGIB]. In Poland, property rights are documented, as in other European countries, by two institutions: land and mortgage register courts and the real estate property cadastre [Hycner 2004]. The first safeguards ownership right by using cadastral data for this purpose, while the other determines based on the data contained in the land and mortgage registers, or maintains the maps with the determined range of ownership right for a given plot. In order to unambiguously determine the scope of ownership rights, it is necessary to carry out geodetic proceedings aimed at determining the course of plot boundaries. During such procedure, the extent of rights assigned to the given real estate property is determined, while designating and marking border points of neighbouring properties in the field. The boundary established in this way has the status of a legal boundary, which has not only legal and geodetic significance, but also social and sociological implications [Felcenloben 2018].

\section{Research problem and methodology}

The task of the starosta (the governor of the poviat, i.e. district), in accordance with Article 4 paragraph 1a, point 2 of the Act on Geodetic and Cartographic Law [PGIK], consists in maintaining the records of the district's geodetic and cartographic resources, including land and building records and soil science classification of land, and entails, among other things, maintaining and updating the land and buildings records. This requirement means that the starosta is obliged to register all changes as to the subject and object of the records, based on geodetic and cartographic documentation [Akińcza 2015]. Theoretically, it can be assumed that when downloading the registration data in the form of an excerpt from the land register or an excerpt from the cadastral map, they should be current and consistent with the factual and legal status. In practice, however, there are a number of inconsistencies arising from factual or legal status. These discrepancies are manifested, among others, by:

a) different courses of boundaries between field boundaries and those marked in the records,

b) different designations of land use compared to the actual situation in the field,

c) different designation of the arable land in the records, in relation to the actual land use,

d) changes in land use, e.g. exclusion of land from agricultural or forestry production,

e) indications of use that are not in accordance with applicable regulations,

f) negligence resulting from the lack of regulation of legal status,

g) address changes of specific entities,

h) mistakes and incorrectly entered data. 
The updating of the land and building records data is carried out in a registry procedure, i.e. it is secondary to legal and geodetic events. Each survey accepted into the geodetic and cartographic resources results in the acceptance of indisputable changes introduced by this survey [syg. Akt II SA/Ke 634/07].

In addition to the changes adopted and approved in the above-described basic mode, i.e. the so-called material and technical mode, there is also the option of the administrative mode (qualified mode). The first one occurs when the authority keeping the land and building records has no doubts as to whether changes have been made (there exists a notarial deed, an entry in the land and mortgage register, an entry in the PESEL, REGON, or TERYT registers), whereas the other applies at the time when updating the survey requires adding new evidence or explanations of the parties involved. Administrative procedure ends with a decision in the given case, or information about the lack of grounds for such a decision.

The source of data used in the process of keeping records is also very important, which is indicated in the table below, presenting the source of registration data as illustrated with the example of a building record (Table 1).

Table 1. Sources of data used in updating land and building records

\begin{tabular}{|c|c|c|}
\hline No. & Type of data & Source of data \\
\hline 1 & Data on plot boundaries & $\begin{array}{l}\text { ODGiK - reports existing in the State geodetic and } \\
\text { cartographic records }\end{array}$ \\
\hline 2 & $\begin{array}{l}\text { Spatial and descriptive data on } \\
\text { the buildings }\end{array}$ & $\begin{array}{l}\text { Wydział Nadzoru Budowlanego (Construction Supervision } \\
\text { Authority) - architecture and construction documentation, } \\
\text { stock-taking documentation, site visit reports, digital } \\
\text { otrophotomap }\end{array}$ \\
\hline 3 & $\begin{array}{l}\text { Descriptive data pertaining to } \\
\text { particular premises }\end{array}$ & $\begin{array}{l}\text { Wydział Nadzoru Budowlanego (Construction Supervision } \\
\text { Authority) - architecture and construction documentation, } \\
\text { stock-taking documentation, appropriate certificate from } \\
\text { the district governor office }\end{array}$ \\
\hline 4 & Value of the land & $\begin{array}{l}\text { Report on the general taxation of real estate properties } \\
\text { (currently not conducted!); the value entered from the } \\
\text { register of real estate prices and values }\end{array}$ \\
\hline 5 & $\begin{array}{l}\text { Sequence numbers of real estate } \\
\text { properties }\end{array}$ & $\begin{array}{l}\text { Municipal office - records of real estate properties sequence } \\
\text { numbers }\end{array}$ \\
\hline 6 & $\begin{array}{l}\text { Number of land register (ledger) } \\
\text { or a collection of documents }\end{array}$ & $\begin{array}{l}\text { District courts - land and buildings registers and document } \\
\text { collections }\end{array}$ \\
\hline 7 & $\begin{array}{l}\text { Other documents determining } \\
\text { ownership }\end{array}$ & $\begin{array}{l}\text { Notarial deeds, final administrative decisions, lawful } \\
\text { (unappealable) court decisions }\end{array}$ \\
\hline
\end{tabular}

Source: Authors' own study

As the table above indicates, there exist attributes that do not have only one data source, which can cause conflicts when different information appears in various regis- 
ters or records. This fact may affect not only the updated new data, but above all the former, existing data, as well as posing the risk that registers without a hierarchical structure will be incorrectly updated. In addition, the example contained in the table indicates that despite the obligation to keep and maintain data on the value of the property, the lack of universal property taxation prevents the proper updating of pertinent attributes.

Another issue concerns the method of registration. Even fully up-to-date information, which had been correctly recorded (from the point of view of current regulations at the time) does not guarantee the possibility of unambiguous identification of the scope of property rights. The authors of the publication conducted a field study in several selected locations, in order to verify the thesis resulting from their hypotheses and analyses. The results of the studies are presented in the next subsection of the article.

\section{Study results}

The discussion regarding the issue of updating the records based solely on the analysis of procedures have expounded the ambiguity of the latter, indicating above all the dualism of the kept records. The fundamental problem is not institutional (on the level of poviat - that is, district authorities, as well as land and mortgage register court), but the lack of a hierarchical structure of records, as well as new legal regulations, which introduced a number of changes that do not have reflection in reality (no common taxation of real estate).

An important issue from the point of view of recording boundaries in the land and building records are the principles set out in $\$ 9$ point 3 of the regulation on land and building records [EGIB], which provides that in the event of intersection between lands seized under railway lines, public roads or canals, for which due to the lack of the land and mortgage records or other documents it is impossible to determine the persons to whom the right of ownership or participation in a land community belongs, hereinafter referred to as "land of unknown owner", when determining the boundaries of registration plots, the following rules shall apply:

a) Railway lines built on the plot divide public roads built on the plot of land into separate cadastral plots,

b) Higher category roads built on the ground divide the lower category roads into separate land plots,

c) Roads and railways built on the ground divide roads and railways built in tunnels and overpasses into separate cadastral plots,

d) Public roads divide internal roads into separate land plots,

e) Covered canals and pipelines do not divide railway lines or public roads into separate cadastral plots.

The criteria adopted in this way, although they are rational from the point of $2 \mathrm{D}$ map guidance, may nevertheless introduce some ambiguity. As is apparent a fragment of the road is located on a railway plot according to a two-dimensional cadastral map 
(Fig. 1). The correct presentation of this situation is not possible without the use of a multidimensional cadastre. From the point of view of a cadastral map kept in two dimensions, it is not possible to unambiguously determine the scope of ownership of the land (Figs 1, 2, 3, and 4).

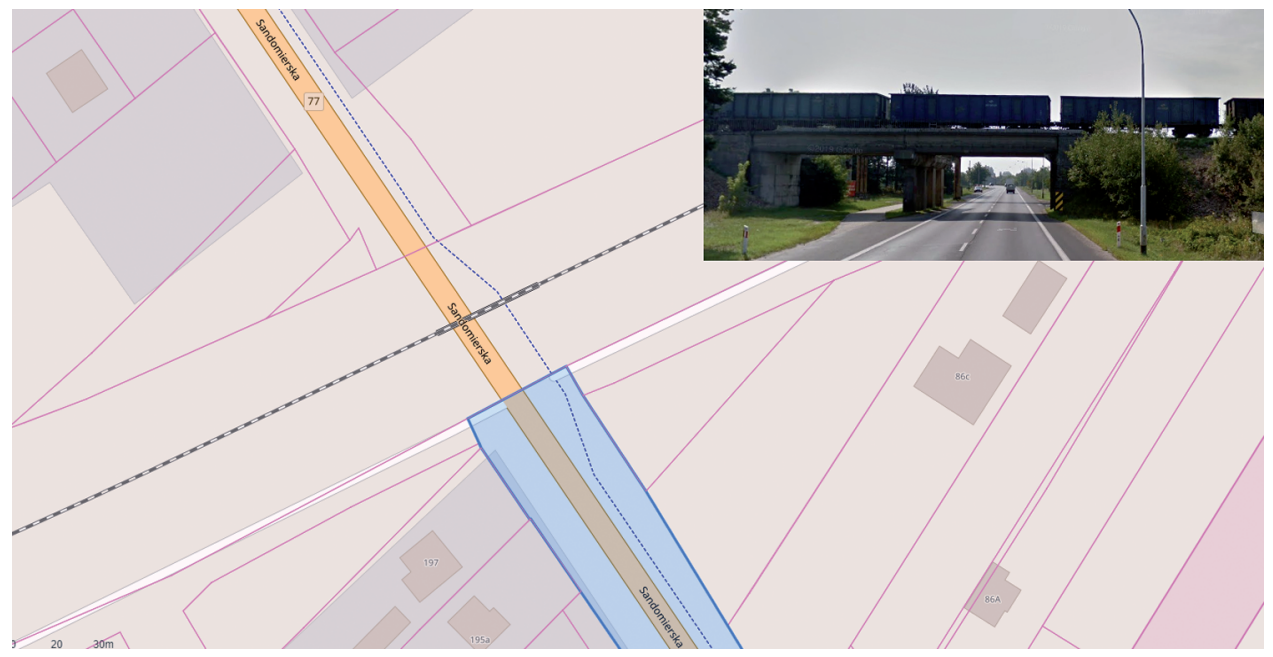

Source: Authors' own study

Fig. 1. Procedure of determining boundaries of land plots in Nisko at Sandomierska street

The second case, concerning the city of Krakow (Fig. 2), illustrates the situation in which it is not possible to properly verify the scope of rights assigned to plots on a two-dimensional map. The plot with a watercourse crosses the road plot, therefore, in this case the owners will vary. Less than 50 meters away from the place where the watercourse flows, there is an intersection of roads. Of course, legislative regulations determine this particular case, which does not change the fact that in the case of different owners or road managers, doubts arise as to the scope of ownership, when guided only by a two-dimensional map, of course.

The following example (Figs 3 and 4) presents a situation in which a natural watercourse was not recorded on the $2 \mathrm{D}$ cadastral map. When reading the map of the records directly, it is possible to get a wrong impression about even the administrator/owner/ manager of the watercourse. A two-dimensional map does not facilitate a presentation of the extent of property rights in the given area.

The above case is also interesting from the point of view of the existing provisions of the Regulation on land and buildings records [EGIB]. Pursuant to $\$ 9$ section $3 \mathrm{a}$, the land occupied by a natural watercourse is a separate cadastral plot within the banks of that watercourse, regardless of whether the water in this watercourse flows along a natural riverbed or a regulated riverbed, open or covered. 


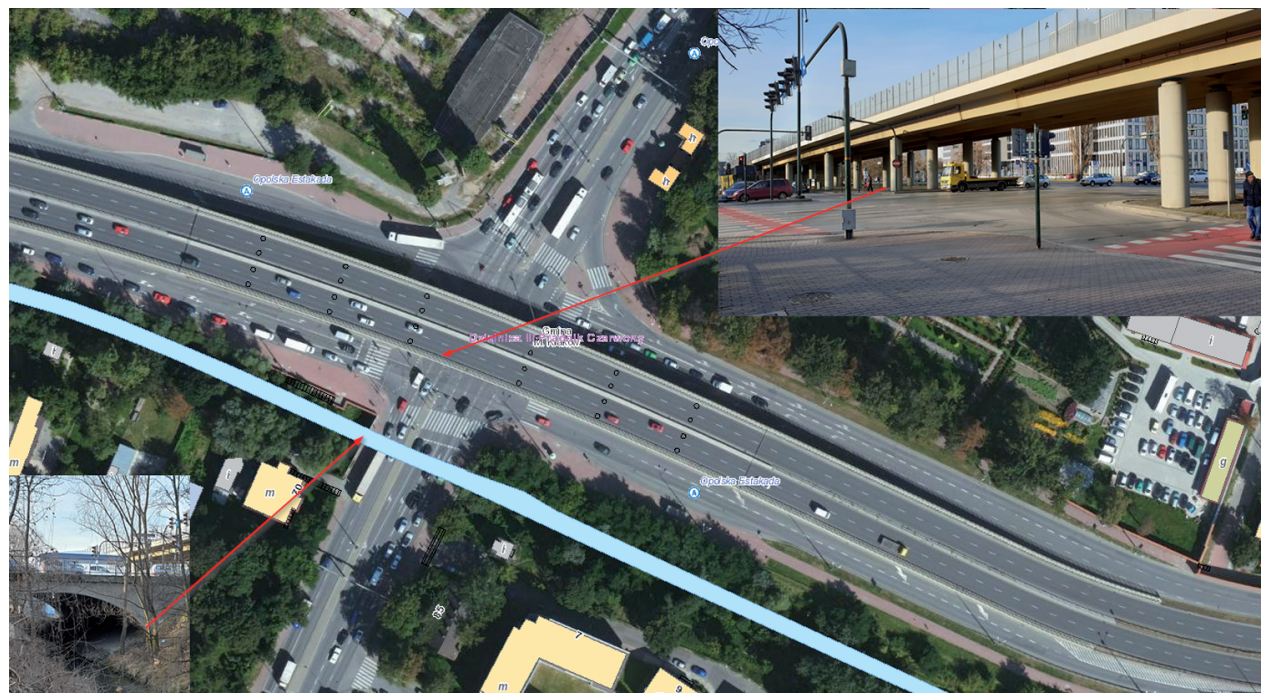

Source: Authors' own study

Fig. 2. Procedure of determining boundaries of land plots at the street of al. 29 Listopada

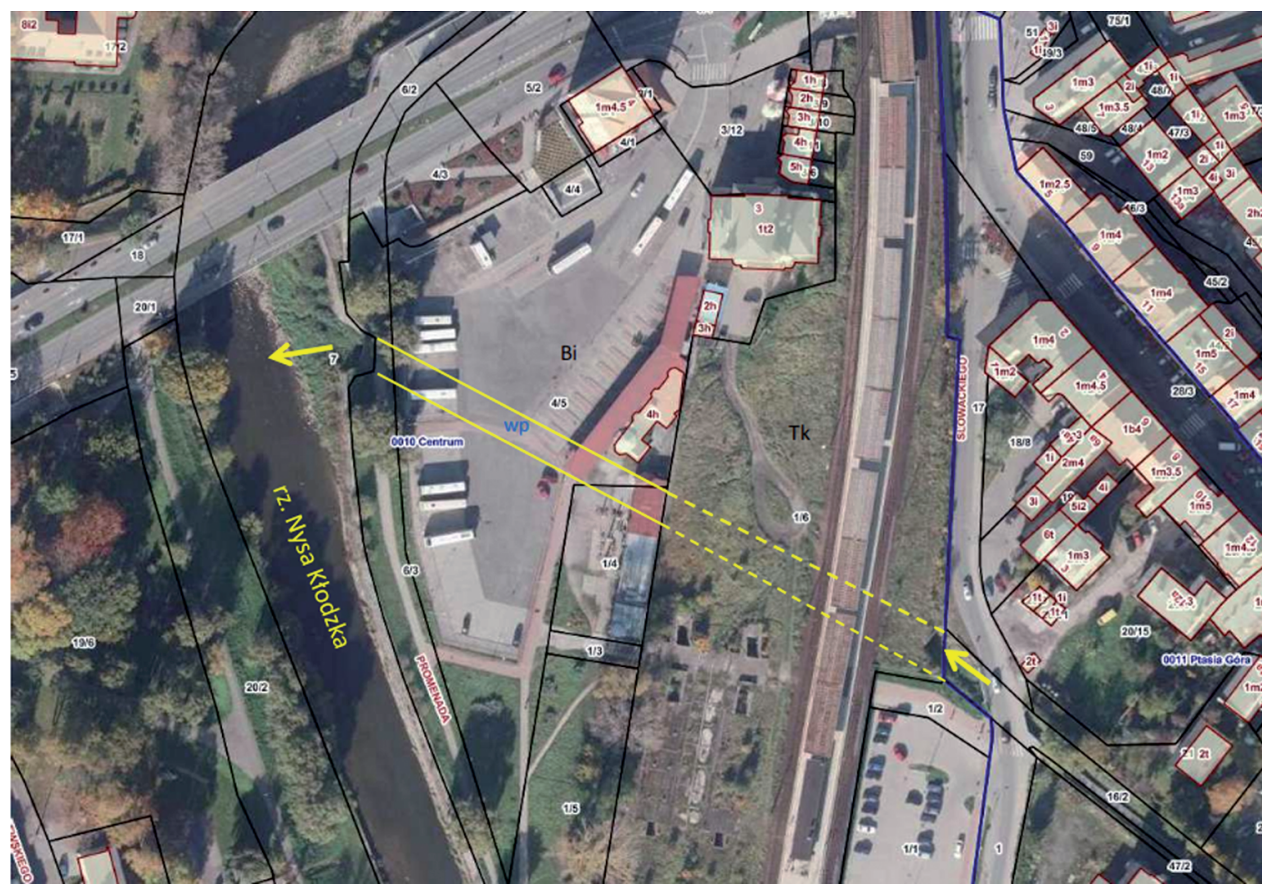

Source: Felcenloben [2015]

Fig. 3. Procedure of determining boundaries of land plots next to Nysa Kłodzka river 
$\S 9$ section 3a of the Regulation on land and buildings records

Land occupied by a natural watercourse constitutes a separate cadastral plot within the banks of that watercourse,

regardless of whether the water in that watercourse flows along a natural riverbed or a regulated riverbed, open or covered
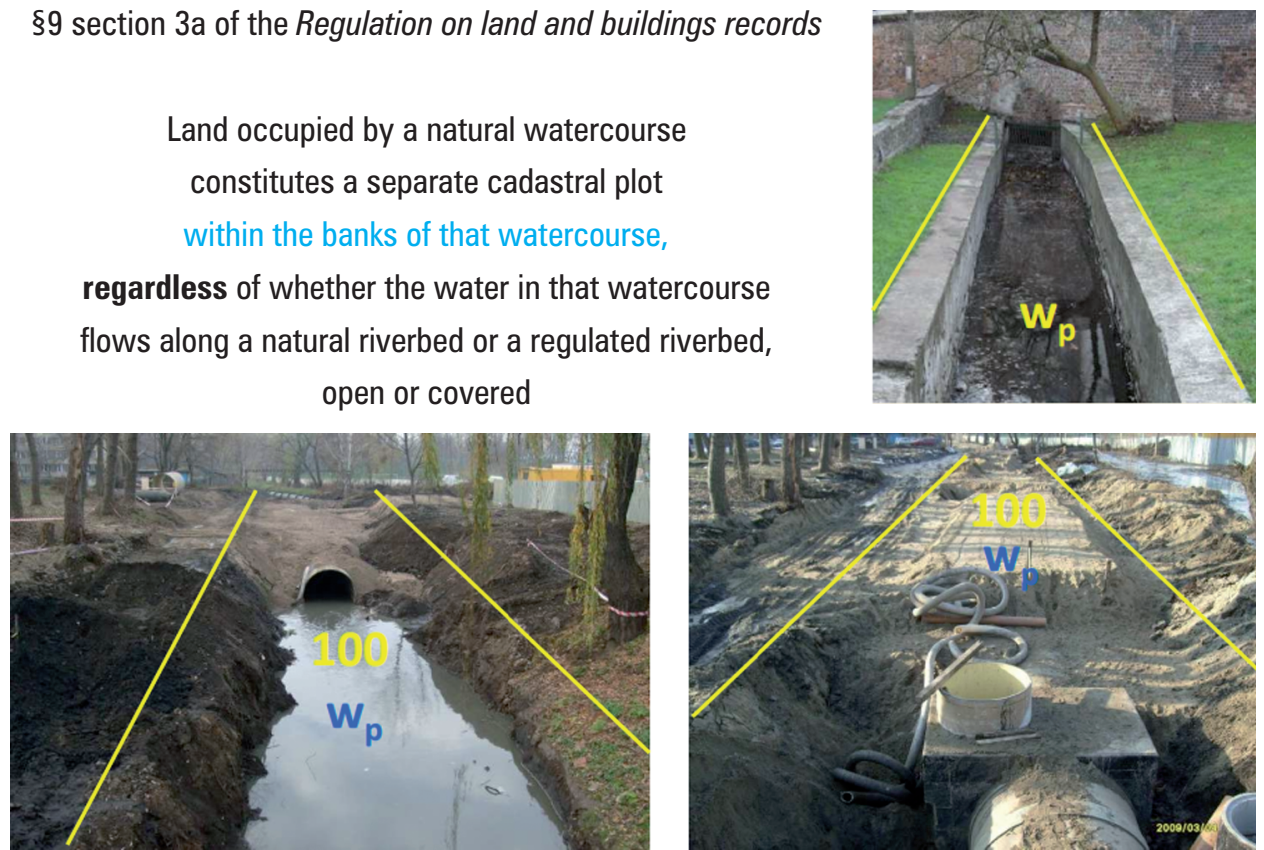

Source: Felcenloben [2015]

Fig. 4. Determining the line of the banks [Prawo Wodne/Water Law]

In this author's opinion, one way to solve the current problems associated with setting boundaries in the above-mentioned cases would be to introduce a multidimensional cadastre that would allow for unambiguous identification of the scope of property rights.

\section{Conclusions}

The land and building records contain data on land, buildings and premises in terms of their location, as well as their physical and legal features. In addition to graphic data, descriptive data is also provided as part of the land and building records. These data records are institutionally maintained by appropriate departments of land and mortgage register courts. In order to maintain uniformity, descriptive data and graphic data records should be identical, and in the case of updating one register, it is necessary to allow for efficient two-way flow. Updating the land and building records is an extremely important issue from the point of view of the country's economic development. It affects the size of investment projects as well as efficient reconstruction of the agrarian structure. The issue raised is also important from the point of view of the individual, because it guarantees safe real estate trading, provides access to mortgage loans, and has an impact on the protection of property rights. 
The current record of plots in two-dimensional format may soon prove to be insufficient, and it will be necessary to replace it with another type of register that would take into account the record of spatial objects. It can therefore be assumed that in the coming years the development of technology will allow three-dimensional visualization of the range of spatial rights assigned to real estate properties.

According to the authors, research conducted with the view to developing a modern concept of a multidimensional cadastre is of utmost importance. According to that concept, the real estate cadastre plays a crucial role, especially in the real estate management process, ensuring effective protection of property rights.

\section{References}

Akińcza M., Bieda A., Buśko M., Hannibal H., Hanus P., Hycner R., Krzyżek R., Kwartnik-Pruc A., Łuczyński R., Przewięźlikowska A. 2015. Aktualne problemy katastru w Polsce. Oficyna Wydawnicza Politechniki Warszawskiej, Warszawa.

Felcenloben D. Narada geodetów powiatowych województwa dolnośląskiego, 20-21.04.2015.

Felcenloben D. 2018. XXI Kaliska Konferencja Naukowo-Techniczna, 18-20.09.2018.

Hycner R. 2004. Podstawy katastru. Uczelniane Wydawnictwa Naukowo-Dydaktyczne, Kraków. Rozporządzenie Ministra Rozwoju Regionalnego i Budownictwa z dnia 29 marca 2001 r. w sprawie ewidencji gruntów i budynków (Dz. U. z 2001 r. Nr 38, poz. 454 ze zm.).

Ustawa z dnia 17 maja 1989 r. - Prawo geodezyjne i kartograficzne (Dz. U. z 1989 r. Nr 30, poz. 163).

Ustawa z dnia 20 lipca 2017 r. - Prawo wodne (Dz. U. z 2017 r., poz. 1566).

Wyrok Wojewódzkiego Sądu Administracyjnego w Kielcach z dnia 21.12.2007 r., syg. Akt II SA/ Ke 634/07.

Dr inż. Szczepan Budkowski

GEO-Mapa Szczepan Budkowski

e-mail: szbudkowski@o2.pl

Dr inż. Jacek Gniadek

Uniwersytet Rolniczy w Krakowie

Katedra Geodezji Rolnej, Katastru i Fotogrametrii

30-198 Kraków, ul. Balicka 253a

e-mail: jacek.gniadek@urk.edu.pl

ORCID: 0000-0003-4381-5018 